\title{
Empirical Analysis on Influence of EET Annuity Tax Policy on Chinese Enterprises
}

\author{
Zhao Miao \\ Beijing Information Science \& Technology University Beijing, China \\ zm_bim@163.com
}

Keywords: enterprise annuity; pension; tax policy; EET mode

\begin{abstract}
The EET annuity tax mode has been implemented in China since 2004. This paper makes a empirical analysis on the influence of EET policy on Chinese enterprises after implementation. We designs three research hypotheses: H1: The EET tax mode enhances the enthusiasm of employees o $\mathrm{n}$ taking part in the enterprise annuity system; H2:The status of economic development spirits the ent husiasm of enthusiasm of employees on taking part in the enterprise annuity system; H3:The develop ment of basic endowment insurance impairs enthusiasm of enterprises' employees on taking part in $t$ he enterprise annuity system. LnPension $=\beta 0+\beta 1 \mathrm{Tax}+\beta 2 \mathrm{GDP}+\beta 3$ Unemployment $+\beta 4 \mathrm{LnRevenue}+\beta 5$ Return $+\beta 6 \mathrm{LnBasic}+\varepsilon$.It has drawn a conclusion that the reform of Chinese enterprise annuity tax pol icy from TEE mode to EET had not facilitated the development of enterprise annuity. The reason is $t$ hat the effect of such policy has not been seen clearly as it was just launched, gives some interpretati ons and suggestions for the Chinese government and enterprises.
\end{abstract}

\section{Introduction}

China is a big country in population. With the trend of aging, the elder support issue becomes more serious in China. Enterprise annuity is an important link of Chinese endowment assurance system. However, in a long period Chinese enterprise annuity system develops slow, not matching the economic development in this country. Many scholars believe that the tax policy is a main factor influencing the development of enterprise annuity. Before 2014, tax policy was TEE mode in China; EET mode has been implemented since 2014, further gearing up to the enterprise annuity tax mode in development countries in the world. The development of Chinese enterprise annuity is in a key phase of advance with big strides. Therefore, this paper conducts empirical analysis on the status of annuity development in China after that tax policy reform.

\section{The Principle of RSA Algorithm}

\section{A. Tax policy}

Enterprise annuity is also called employer's annuity and enterprise pension. On January 6, 2004, the "Measures of Trail Implementation of Enterprise Annuity" promulgated by former Ministry of Labor Social Assurance defines it as a supplementary endowment insurance established by enterprise and employees voluntarily besides basic endowment insurance.

World Bank has recommended the endowment assurance mode of three pillars-public endowment insurance, enterprise annuity plan and personal saving endowment insurance. Of them, the enterprise annuity plan is the second biggest pillars of the endowment assurance mode and an integral part to endowment assurance system of all countries.

Today, Chinese enterprise annuity cannot match the economic development no matter in participation rate, substitution rate or in the proportion of assets in GDP. The academy believes that the enterprise annuity tax policy is a key factor influencing the development of enterprise annuity. The 
enterprise annuity tax policy is not only a significant factor of the country to push for enterprise annuity system, but also an consideration for enterprises to establish their own annuity plans and individuals to take part in the annuity plans.

B. Influence of enterprise annuity tax policy on enterprises

The enterprise annuity tax is mainly reflected in three links: payment, investment and receiving. There are eight tax modes as to the conditions of tax levy on different links. The details are as the table 1 below:

Table 1. ENTERPRISE ANNUNITY TAX MODES (E-EXEMPTION,T-LEVY)

\begin{tabular}{|l|c|c|c|c|c|c|c|c|}
\hline & EEE & EET & ETE & TEE & ETT & TET & TTE & TTT \\
\hline Payment & E & E & E & T & E & T & T & T \\
\hline Investment & E & E & T & E & T & E & T & T \\
\hline Receiving & $\mathrm{E}$ & $\mathrm{T}$ & $\mathrm{E}$ & $\mathrm{E}$ & $\mathrm{T}$ & $\mathrm{T}$ & $\mathrm{E}$ & $\mathrm{T}$ \\
\hline
\end{tabular}

EEE and TTT are two most unreasonable tax modes in above eight modes. EEE means exempting all links from taxes as the most preferred tax policy and can inspirit the enthusiasm of the enterprises and employees to take part in and establish enterprise annuity. However, the tax expenditure of such tax mode is too high, which means the national tax loss is the highest. We can image many employees of enterprises including especially those high-income groups will avoid the tax by this mean. TTT is a tax mode levying tax in all links and can bring the government the most tax incomes. However, it also gives right to the issue of repeated tax levy to a certain extent. Especially TET mode brings serious issue of repeated tax levy, impairing the enthusiasm of the enterprises and employees, so it cannot help the development of enterprise annuity tax. ETE mode will not bring issue of repeated tax levy, but under this mode only investment link is taxable. Under this mode, the national tax base is small and the government will face a large tax income loss. Besides, the tax exemption in payment and receiving links is against the tax principle, so this mode is adopted only in rare countries. EET and TEE are enterprise annuity tax modes adopted in most of countries in the world.

\section{Hypotheses}

Assuming that enterprise annuity tax is levied in receiving link, for individual, the incomes after retirement will be reduced and the tax rate for annuity received will be less than the rate for incomes during service period, therefore, employee would like to pay tax in receiving link and be exempted from tax in payment link. In the analysis in previous part, TEE and EET are the most reasonable modes, especially for EET mode. Chinese government has reformed the tax mode from TEE to EET since 2014. By comparison with TEE, EET inspirits employees to take part in enterprise annuity plan more. We measure the enthusiasm of enterprise employees on taking part in annuity plan with the average contribution of employees joining annuity plan and thus bring out our hypotheses:

H1: EET tax mode enhances the enthusiasm of enterprises' employees on taking part in the enterprise annuity system, i.e. the two variables are related to each other positively.

Economic development is a key factor influencing development of enterprise annuity. Generally speaking, when economic development is better, the economic growth is stable, enterprise receives more profits, employees have reliable and stable income and considerable anticipated incomes, and thus willing to take part in annuity plan; in such cases, the unemployment rate is low, the jobs are stable and the employees have higher financial strength to take part in the plan; the disposable incomes are increased, so more funds can be used for annuity fund; the more the investment yield of enterprise annuity is, the better the ability of annuity in value maintenance and addition is, and the higher the enthusiasm of employees on taking part in the annuity plan is. Therefore we chose GDP growth rate, urban registered unemployment rate, average disposable incomes of urban residents and annuity yield as factors in measuring the status of economic development and brought following 
hypotheses:

H2: the status of economic development spirits the enthusiasm of enthusiasm of enterprises' employees on taking part in the enterprise annuity system, i.e. they are related to each other positively.

Besides, the basic endowment insurance features high participation rate as one of three pillars of endowment assurance. It is also influences the development of enterprise annuity a lot. There is indistinct substitution between the two pillars. So we brought following hypothesis:

H3: the development of basic endowment insurance impairs enthusiasm of enterprises' employees on taking part in the enterprise annuity system, i.e. the two variables are related to each other negatively.

\section{Empirical analysis}

\section{A. Modeling}

Based on above analysis, considering other factors influencing the enthusiasm of enterprise employees on joining annuity plan, we established following regression model:

LnPension $=\beta 0+\beta 1$ Tax $+\beta 2$ GDP $+\beta 3$ Unemployment $+\beta 4$ LnRevenue $+\beta 5$ Return $+\beta 6$ LnBasic $+\varepsilon$

The relevant variables in the model shall be interpreted as below table 2:

Table 2. INTERPRETATIONS OF VARIABLES IN MODEL

\begin{tabular}{|l|l|c|}
\hline \multicolumn{2}{|l|}{ Variable } & \multicolumn{1}{c|}{$\begin{array}{c}\text { Anticipated } \\
\text { correlativity }\end{array}$} \\
\hline $\begin{array}{l}\text { Dependent } \\
\text { variable }\end{array}$ & LnPension & + \\
\hline \multirow{4}{*}{$\begin{array}{l}\text { Independent } \\
\text { variable }\end{array}$} & Tax & + \\
\cline { 2 - 3 } & GDP & - \\
\cline { 2 - 3 } & Unemployment & + \\
\cline { 2 - 3 } & LnRevenue & + \\
\cline { 2 - 3 } & Return & + \\
\cline { 2 - 3 } & LnBasic & + \\
\hline
\end{tabular}

Table 3. MEANING OF INDEPENDENT VARIABLE

\begin{tabular}{|l|c|}
\hline Variable & Meaning \\
\hline LnPension & Natural logarithm of average payment of employees in enterprise \\
\hline Tax & EET tax mode is "1" and TEE is "0" \\
\hline GDP & GDP growth rate \\
\hline $\begin{array}{l}\text { Unemploy } \\
\text { ment }\end{array}$ & Natural logarithm of average disposable incomes of urban residents \\
\hline LnRevenue & Enterprise annuity investment yield \\
\hline Return & Natural logarithm of incomes of basic endowment insurance fund of urban employees in \\
& current period \\
LnBasic & \\
\hline
\end{tabular}

\section{B. Data analysis}

The data of tax model variable in above seven variables was obtained through judgment on different tax modes according to the circular (Cai Shui (2013) No. 103) jointly released by on the Ministry of Finance, Ministry of Human Resources and Social Assurance and State Taxation Bureau, December 6, 2013; other six variables were originated from data and information of websites of 
Ministry of Finance, Ministry of Human Resources and Social Assurance and State Statistics Bureau. When selecting data, the author selected the statistic data of each quarter during 2013-2014. Taking data of a single quarter as a sample, we obtained all data from numerical values in relevant quarter except the accumulated numerical values in previous period. We have acquired eight effective samples. We made descriptive analysis on samples with SPSS, as shown as Table 4:

Table 4. SAMPLE DESCRIPTIVE ANALYSIS DESCRIPTIVE STATISTICS

\begin{tabular}{|c|c|c|c|c|c|c|}
\hline & $\mathrm{N}$ & $\begin{array}{l}\text { Min } \\
\text { imum }\end{array}$ & $\begin{array}{l}\text { Max } \\
\text { imum }\end{array}$ & $\begin{array}{c}\text { Average } \\
\text { value }\end{array}$ & $\begin{array}{l}\text { Standard } \\
\text { deviation }\end{array}$ & Variance \\
\hline Tax & 8 & 356.61 & 677.57 & 469.8362 & 108.57140 & 11787.748 \\
\hline GDP & 8 & 0 & 1 & .50 & .535 & .286 \\
\hline Unemployment & 8 & 1.50 & 2.3 & 18250 & .24928 & .062 \\
\hline LnRevenue(yuan & 8 & 4.07 & 4.10 & 4.0837 & .01061 & .000 \\
\hline LnRevenue & & & & & & \\
\hline Return ( $100 \mathrm{M}$ ) & 8 & 6043.13 & 7911.89 & 6913.8563 & 565.70112 & 320017.755 \\
\hline LnBasic & 8 & .12 & 3.37 & 3.6250 & 1.02493 & 1.050 \\
\hline $\mathrm{N}$ & 8 & 4930.30 & 7543.88 & 5966.9863 & 830.89683 & 690389.534 \\
\hline
\end{tabular}

Above table shows, the value range of average quarterly payment of employees of enterprises is RMB 356.61-677.57 during 2013-2014 and the average value for all employees joining the plan is approx RMB 469.84. As to tax mode, TEE mode was adopted in the four quarters in 2013 and the value is 0 ; EET mode was adopted in the four quarters in 2014 and the value is 1 . Any of variances of GDP growth rate and urban registered unemployment rate is close to 0 , meaning the minor fluctuation of both. In other words, the macro-economy of China is stable in this period. The maximum and minimum of the average disposable incomes of urban residences are RMB 7911.89 and RMB 6043.13 respectively, with a gap of nearly RMB 2000; the maximum and minimum of the enterprise annuity investment yield is $3.37 \%$ and $0.12 \%$ respectively, with a large gap, which means undeveloped financial market in China in stable macro-economy.

\section{Correlation analysis}

We have made correlation analysis aiming at tax mode and average payment of employees and draw a conclusion as Table 5:

Table 5. CORRELATION ANALYSIS OF TAX MODE AND PAYMENT OF EMPLOYEES CORRELATITY

\begin{tabular}{|c|c|c|c|}
\hline & & $\begin{array}{l}\text { Natural logarithm of average } \\
\text { payment of } \\
\text { employees (yuan) }\end{array}$ & Tax mode \\
\hline $\begin{array}{l}\text { Natural logarithm of } \\
\text { average } \\
\text { payment of } \\
\text { employees }\end{array}$ & $\begin{array}{l}\text { Pearson correlation } \\
\text { Significance } \\
\text { (two sides) } \\
\text { N }\end{array}$ & 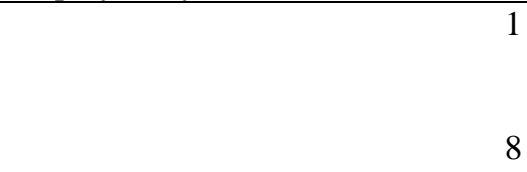 & $\begin{array}{r}-.374 \\
.362 \\
8\end{array}$ \\
\hline Tax mode & $\begin{array}{l}\text { Pearson correlation } \\
\text { Significance } \\
\text { (two sides) } \\
\text { N }\end{array}$ & $\begin{array}{r}-.374 \\
.362 \\
8\end{array}$ & $\begin{array}{l}3 \\
8\end{array}$ \\
\hline
\end{tabular}

This table shows, the Pearson correlation coefficient $r$ between natural logarithm of average payment of employees and tax mode is -0.374 and the absolute value $|r|=0.374$, indicating that there is a low correlation between natural logarithm of average payment of employees and tax mode and the significance level between them is 0.362 . This is contrary to foresaid $\mathrm{H} 1$ possibly for two reasons: first, the data sample size is too small because Chinese enterprise annuity tax mode has not shown significant effect as it was just changed from TEE to EET; secondly, Chinese tax preference is not enough. A certain preference of cost deduction has been provided for enterprise payment, so currently only personal payment part is exempted; thirdly, since the 18th National Congress of the CPC, central government has strengthened the anti-corruption actions and reduced the salary level of employees, 
especially senior management of state-owned enterprises. It may also a reason for negative correlation between natural logarithm of average payment of employees and tax mode.

\section{D.Multiple linear regression analysis}

We have made multiple linear regression analysis with above model and draw a conclusion shown as Tables 6-9:

Table 6. VARIABLES INPUT IN/REMOVED FROM MULTIPLE REGRESSION ANALYSIS INPUT IN ${ }^{\mathrm{a}}$ /REMOVED VARIABLES ${ }^{\mathrm{b}}$

\begin{tabular}{|l|l|c|c|}
\hline Model & \multicolumn{1}{|c|}{ Input variable } & $\begin{array}{l}\text { Removed } \\
\text { variable }\end{array}$ & Method \\
\hline 1 & $\begin{array}{l}\text { Natural logarithm of incomes of basic } \\
\text { endowment insurance fund in } \\
\text { current period (RMB 100 M); } \\
\text { natural logarithm of average disposable incomes } \\
\text { of urban residents (RMB yuan); enterprise } \\
\text { annuity investment yield (\&); } \\
\begin{array}{l}\text { GDP growth rate (\%); } \\
\text { tax mode, urban registered unemployment rate (\%) }\end{array}\end{array}$ & $*$ & Input \\
\hline
\end{tabular}

a. All request variables have been input.

b. Dependent variable: natural logarithm of average payment of employees (RMB yuan)

Tab. 6 shows, in the multiple liner regression analysis, the input variables are all independent variables and there is variable eliminated.

Table $7 . \quad$ SUMMARY ON EVALUATION ON TEST RESULT OF MULTIVARIATE REGRESSION MODEL MODEL SUMMARY

\begin{tabular}{|r|r|r|r|r|r|}
\hline Model & $\mathrm{R}$ & R variance & $\begin{array}{c}\text { Adjusted R } \\
\text { variance }\end{array}$ & $\begin{array}{c}\text { Standard } \\
\text { deviation }\end{array}$ & $\begin{array}{r}\text { Durbin- } \\
\text { Watson }\end{array}$ \\
\hline 1 & $1^{\mathrm{a}}$. & 1.000 & 1.000 & 0.00315 & 2.717 \\
\hline
\end{tabular}

a. Anticipated variables (constants), Natural logarithm of incomes of basic endowment insurance fund in current period (RMB $100 \mathrm{M}$ ); natural logarithm of average disposable incomes of urban residents (RMB yuan); enterprise annuity investment yield (\&); GDP growth rate (\%); tax mode, urban registered unemployment rate $(\%)$

b. Dependent variable: natural logarithm of average payment of employees (RMB yuan)

We can draw R, R2, adjusted R2 and standard deviation from Tab. 7 The adjusted R2 of such regression model is 1 , indicating the goodness of fit of the regression is very high; D-W is 2.717 , higher than 2 , meaning mutual independence of residuals.

Table 8. RESULT OF VARIANCE ANALYSIS OF MULTIPLE REGRESSION ANALYSIS ANOVA ${ }^{\mathrm{b}}$

\begin{tabular}{|l|r|r|r|r|r|}
\hline Model & Sum of Squares & $\mathrm{df}$ & Mean square & F & Sig. \\
\hline Regression & .333 & 6 & .056 & 5591.278 & .010 \\
Residual & .000 & 1 & .000 & & \\
Total & .333 & 7 & & & \\
\hline
\end{tabular}

a.Anticipated variables (constants), Natural logarithm of incomes of basic endowment insurance fund in current period (RMB $100 \mathrm{M}$ ); natural logarithm of average disposable incomes of urban residents (RMB yuan); enterprise annuity investment yield (\&); GDP growth rate (\%); tax mode, urban registered unemployment rate (\%)

b.Dependent variable: natural logarithm of average payment of employees (RMB yuan)

We can test the significance of regression equation from Tab. 8. The value of $F$ in the regressed part of such regression part is 5591.278, the corresponding probability $\mathrm{P}$ is 0.01 , less than 0.05 , the level of significance. As a result, the interpreting variable is relatively significant to interpreted part of the interpreted variable, so it is reasonable to establish a linear model. 
Tab 9. REGRESSION COEDDICIENTS OF MULIPLE REGRESSION ANALYSIS COEFFICENENTS ${ }^{\mathrm{a}}$

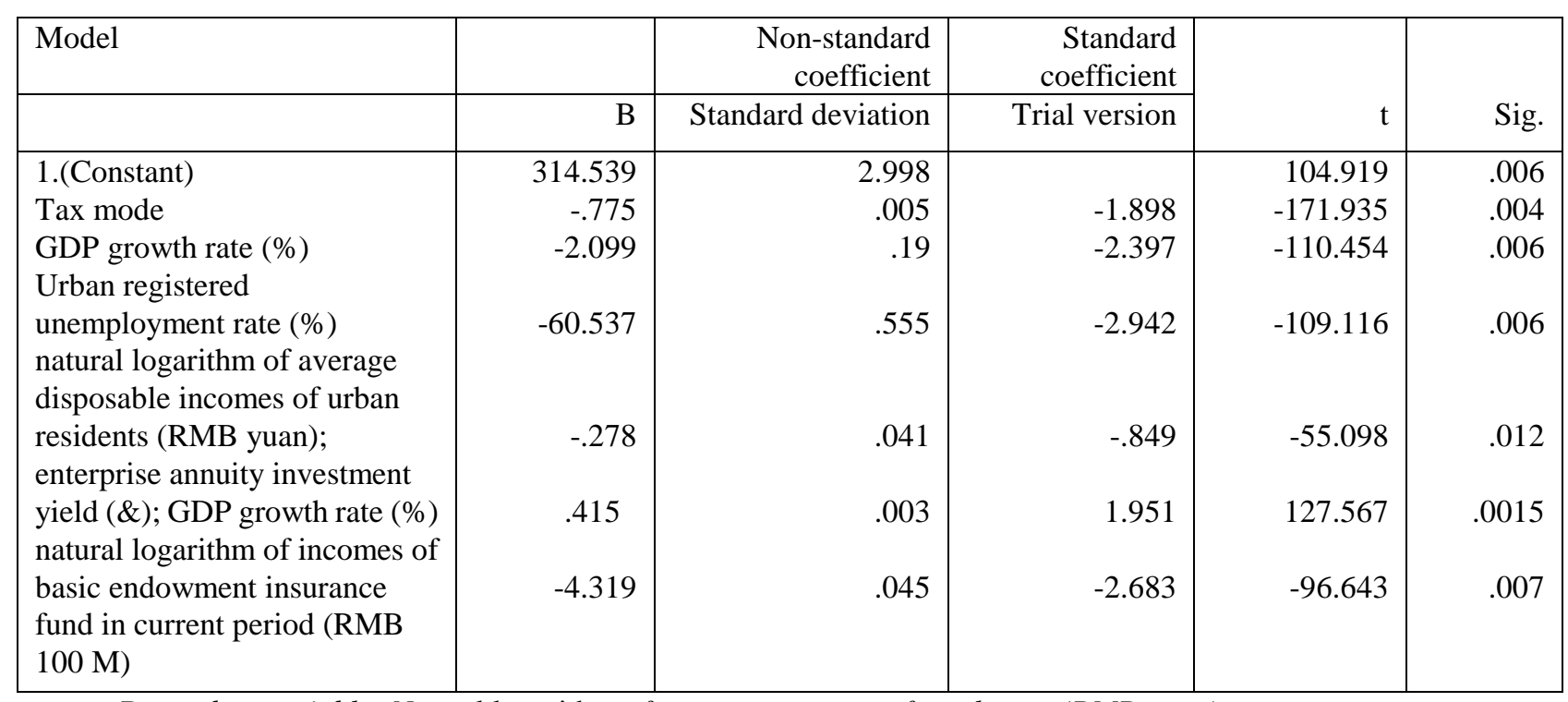

a.Dependent variable: Natural logarithm of average payment of employees (RMB yuan)

Tab. 9 presents the regression coefficient of the linear regression model and some relevant statisti cs. The table shows, the constant of the regression model is 314.539 and the coefficient of tax mode is -1.898 . The coefficient is significant, above $5 \%$, so there is negative relation, inconsistent with $\mathrm{H} 1$ for reasons foresaid.

As to status of national economic development, there is gay between conclusions from different in dicators. There is negative correlation between urban registered unemployment rate and natural logar ithm of average payment by employees; and there is positive correlation between enterprise annuity $i$ nvestment yield rate and natural logarithm of average payment by employees. These are consistent $\mathrm{w}$ ith the hypothesis and the coefficient is significant, above $5 \%$. There is negative correlation between GDP growth rate and natural logarithm of average payment by employees between natural logarithms of GDP growth rate. This is inconsistent with the hypothesis. The reason may be that, the two indep endent variables including GDP growth rate and average disposable incomes of urban residents are macro variables. Generally speaking, the national economy is developing and the disposable income $\mathrm{s}$ of residents are rising. Besides, China is a developing country in its key period of economic transfo rmation. Especially since Chinese government has been adjusting its economic structure since the op ening of the 18th National Congress of the CPC, GDP growth rate may fluctuate more than before an $\mathrm{d}$ the average disposable incomes of urban residents may fluctuate, too. Besides, we take samples in quarters and these macro -economic indicators are related to the quarters to a certain extent. For inst ance, most of enterprises will distribute year-end bonuses to employees in Q4, which will cause the $\mathrm{i}$ ncreased disposable incomes of residents in this phase.

The variable, i.e. the natural logarithm of incomes of basic endowment insurance fund in current period, is the consistent with the anticipated result and negatively related to the natural logarithm of average payment by employees. The coefficient is significant, above $5 \%$, so the original hypothesis $\mathrm{i}$ $\mathrm{s}$ established. Therefore, there is indistinct substitution between basic endowment insurance and ente rprise annuity.

\section{Conclusions}

Above analysis shows, the reform of Chinese enterprise annuity tax policy from TEE to EET has not facilitated the development of enterprise annuity as expected. That is contrary to the theory. How ever, Chinese government has just launched EET tax mode for over 1 year and the facilitating role of EET tax mode in development of enterprise annuity has not been played, plus our analysis restricted by the unavailability of relevant data. Therefore, we cannot deny Chinese enterprise annuity tax refo rm just based on above result. 
We also find that, the economic development of the country has obvious influence on the enterpri se annuity, especially in unemployment rate and enterprise annuity investment yield. Therefore, the government has obligation to maintain stable economic development; as to the investment of enterpr ise annuity, on the premise of constant perfection of Chinese financial market, the government may appropriately loose the restriction on the investment direction of enterprise annuity and ensure the va lue preservation and addition of annuity to push for the development of enterprise annuity. Enterpris e annuity is one of important pillars of elder support system, while social basic endowment insuranc e also has certain influence on development of enterprise annuity. There is indistinct substitution bet ween both pillars. So, during governmental promotion of enterprise annuity system, corporate establi shment of annuity plans and individual participation of annuity fund, all parties shall consider the ma tching and mutual supplement between enterprise annuity fund and basic endowment insurance fund to bring the role of Chinese elder support system to the largest extent.

\section{Acknowledgements}

The author of this paper was supported by Beijing Higher Education Young Elite Teacher Project. Project name: Mobile Banking Risk Management Based on Analysis of Consumers' Will of Use. No:71A1511127

\section{References}

[1] Supervision Department of Ministry of Human Resources and Social Assurance. "Abstract of Business Data of National Enterprise Annuity Fund in 2014”, March, (2015)

[2] State Statistics Bureau. "Data of Human Resources and SocialAssurance in 2015", March, (2015)

[3] Zhou Jianzai, Hu Bingzhi, Dai Baozhen. Research on Deferred Individual Income Tax of Chinese Commercial Endowment Insurance -A Case of Jiangsu (J). Insurance Researches. ， (2012)

[4] Chen Dihong. Analysis on Enterprise Annuity of Deferred Tax in US and Inspiration on China (J). Financial \& Economic Theories and Practices, Issue 1, (2015)

[5] Pu Xiaohong. Analysis on Reason and Countermeasures of Slow Development of Chinese Enterprise Annuity (J). Journal of Anhui University, Issue 1, (2015) 